\title{
Visual Study of Local Coffee Brand Packaging and Its Effect on Consumerism (Case Study: Coffee Brands in Jakarta)
}

\author{
Yunisa Fitri Andriani ${ }^{1}$ and Ratno Suprapto ${ }^{2}$ \\ ${ }^{1,2}$ Faculty of Design and Engineering, Universitas Pembangunan Jaya, Indonesia \\ 1yunisa.fitri@upj.ac.id²ratno.suprapto@upj.ac.id
}

\begin{abstract}
Indonesian coffee has good quality, so it's imported by many other countries. But here, local coffee has been in great demand in recent years. Seen from the proliferation of local coffee shop in Indonesia, especiallyJakarta.In addition to the delicious taste of coffee, this coffee shop also offers an identity for consumers.Through well-designed visuals, ranging from places to packaging, this coffee shop is able to make coffee consumer feel proud to consume them and even share its photos on their social networks. With so many photos of local coffee scattered on cyberspace, and these coffees that are very affordable,the level of consumerism is certainly increasing. Today's local products open new markets, which has a dense population. Considering a new market with a high level of consumerism, this study examines the visual packaging used by contemporary coffee outlets in Jakarta.Regarding the taste, Indonesian coffee no longer needs to be asked, but the biggest question is why now local Indonesian coffee is in great demand. This research uses 2 theories, color psychology and perception psychology, aiming to study the effect of visual packaging on the level of consumerism, and hoped that will be the basis for designing visual marketing products.
\end{abstract}

Keywords: visual, packaging, coffee, consumerism, Jakarta

\section{INTRODUCTION}

Coffee was brought to Indonesia in the Dutch colonial era around the $1700 \mathrm{~s}$. The culture of drinking coffee in Indonesia began since then and continues to this day. Indonesia has also become a producer of quality coffee beans and has exported its coffee beans to many countries. Even though this local coffee has been around for a long time, this recent years local coffee has its own prestige value in Indonesian society.[1] The target market for local coffee has also expanded, which was once the majority of local coffee demanded by adults, now local coffee has entered into the routine of young people in a big city, especially in Jakarta.[2] This can be seen from the proliferation of local coffee outlets that continue to appear in all corners of Jakarta. The majority of these coffee outlets are shaped like stalls selling coffee to take away. Some of these coffee shops provide a comfortable place to enjoy coffee, but the majority only provide a few chairs that are usually used to wait for orders. 
This local coffee shops compares themselves and visualizes their brand very well. The visuals they designed started from logos, interiors to packaging. This makes consumers feel interested in sharing their packaging photos on their own private social networks. The actions taken by these consumers prove that the local coffee brand not only offers coffee drinks, but also offers an identity.[3] Social networks have become very effective media in product marketing. With so many post of coffee in cyberspace, the target market for local coffee has expanded and the level of consumerism has also increased.

The taste and quality of Indonesian coffee is unquestionable, with many countries importing Indonesian coffee, it can be concluded that Indonesian coffee is popular with many people. But why has the level of consumerism in local coffee increased so dramatically in recent years? then this study wants to answer the extent to which the visual packaging of local coffee affects the level of consumerism, especially in the capital.

\section{METHOD}

The method used in this study is the method of collecting data in the form of spreading questionnaires to new target markets for local coffee products, young adults aged 17-35 years. This research also uses the literature study method by linking several theories with their influence on consumer behavior. Theories used are color psychology and perception psychology. These 2 theories are the basis for identifying and examining the visual design of packaging used by local coffee brands in Jakarta. Color psychology studies the different reactions of people on certain colors and how color allows people to assess certain aspects of an object.[4] The results of this identification and visual study will be linked to their effects on the level of consumerism.Consumer buying behavior refers to the overall attitude of a consumer based on personal preferences, beliefs, objectives, and perceptions when buying a product or service.[4]

\section{RESULT AND DISCUSSION}

In 2013, Indonesia exported $19 \%$ of total exports for agricultural commodities, The amount of coffee exports in Indonesia has a promising potential for economic development. The types of coffeeproducts are exported in the form of coffee beans, raw coffee, roasted coffee beans, and in the form of processed coffee (coffee powder). But most of Indonesia's coffee exports to foreign markets are dominated by coffee beans rather than processed coffee.For this type of coffee, robusta and Arabica coffeeis still the main source of Indonesian coffee exports to the United States and EU.[5] So the quality and taste of Indonesian coffee is not in doubt. The reason why only a few years ago local coffee was in great demand by the local population was one of the backgrounds of this research. Not only adults who used to enjoy local coffee, but now young people even enjoy local Indonesian coffee.[6]

Ebert and Griffin (2003:264), state that the consumers buying decisions process involves five stages, i.e. problem recognition, information search, and evaluating of alternatives, purchase decisions, and post purchase decisions the buying process begin when the consumers recognize a problem or need. Consumers then develop attentions in order to seek information that satisfies their perceived needs.[7] The packaging design is the focus of this research, because through packaging, local coffee consumers share their identities on social networks and in everyday life. Packaging at point-of-sale is the last chance a producer has to sway the customer towards their product, and its impact is so significant that it has become known as 
the "silent salesman".[8] Rita Kuykaite (2009) also concluded that packaging could be treated as one of the most valuable tool in today's marketing communication, necessitating more detail analysis of its elements and impact on consumer's purchase decision can be revealed by analyzing an importance of its separate elements for consumer's choice. [9]It proved in how these local coffee consumers are proud to carry it on their activities or share their packaging photos on private social networks. The theory of color psychology will analyze the message and the meaning behind the design of this local coffee shop packaging, because Color psychology studies various shades and its effects on human behavior.[10]

Before analyzing, researchers conducted a survey through a questionnaire to find out which brands could be used as case studies. The following are the results of the questionnaire that has been distributed to the new target market for local coffee products, namely adolescents to young adults, around 17-35years.

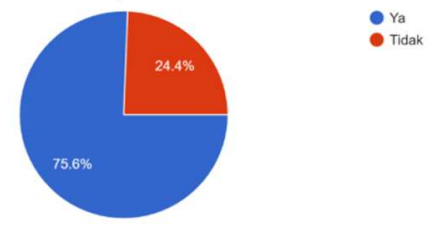

\section{Figure 3.1 First Answer of the Questionnaire}

From the first question of this questionnaire, $75.6 \%$ of respondents answered that they are coffee enthusiasts, and most prefer buying coffee at local coffee shops rather than buying coffee at well-known coffee outlets such as Starbucks. This can be seen in the chart of the results of the questionnaire below. Around $90 \%$ choose local coffee shops. From these results it can be concluded that international coffee outlets began to be displaced by local coffee shops.

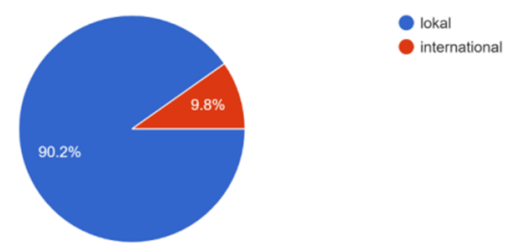

Figure 3.2Second Answer of the Questionnaire

The reason why they prefer local coffee shops is answered in the next question. Half the respondents consider affordable prices as a basis for selecting local coffee shops, and some consider the good taste as the basis for their selection.

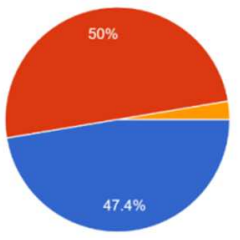

rasanya enak

biar hits dan kekinia

Figure 3.3Third Answer of the Questionnaire

The following is a chart of the results of the local coffee brand survey which respondents liked most: 


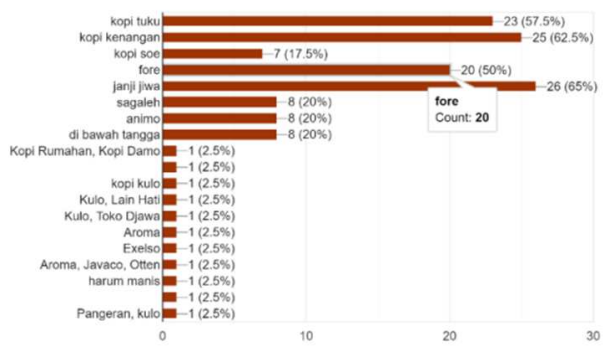

Figure 3.4Forth Answer of the Questionnaire

Based on the chart above, 4 coffee brand samples can be obtained that get the most votes as the most preferred coffee brand and then analyze the packaging visually. The sample chosen by respondents is:

1. Janji Jiwa

2. Kopi Kenangan

3. Kopi Tuku, dan

4. Fore

\subsection{CASE STUDY OF LOCAL COFFEE BRANDS IN JAKARTA}

Like other coffee brand, this 4 coffee brand also present 2 types of coffee, hot coffee and iced coffee. So they use 2 types of coffee packages that are adjusted to the temperature of the coffee. Paper material is used for hot coffee and plastic material is used for iced coffee.
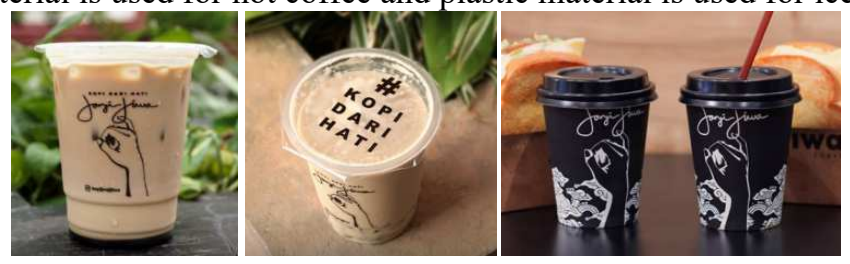

Figure 3.5Janji Jiwa's Packaging

Source : Janji Jiwa official instagram account

The dominant color of the Janji Jiwa coffee packaging is both hot and cold packaging, dominated by black. Black symbolizes elegance, sophistication, prosperity, independent, and full of mystery. This color is the color most preferred by teenagers because of its mystery. Teenagers love mysteries like those who are still searching for identity. In cold coffee packaging, this brand uses transparent plastic material so that the color of coffee dominates the appearance of this package.
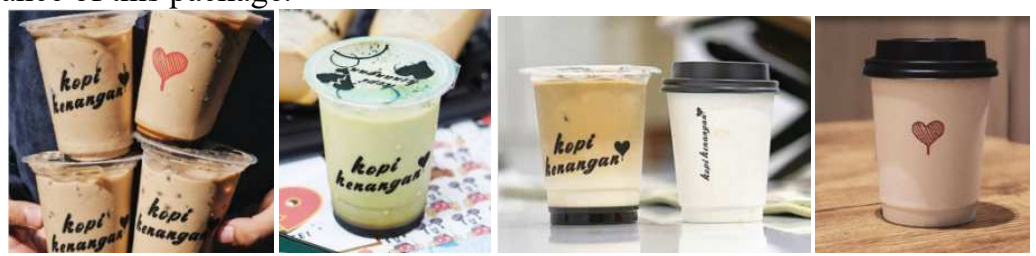

Figure 3.6Kopi Kenangan's Packaging Source : Kopi Kenangan official instagram account 
Almost the same as janji jiwa packaging, kopi kenangan and tuku also chose black as the main color. However, kopi kenangan and tuku use white as the basis for the color of hot coffee packaging. The white color psychologically gives confidence that the quality undoubtable. On the coffee packaging, there is a red color as an accent. Psychologically red color means courage, strength, energy, passion and excitement.

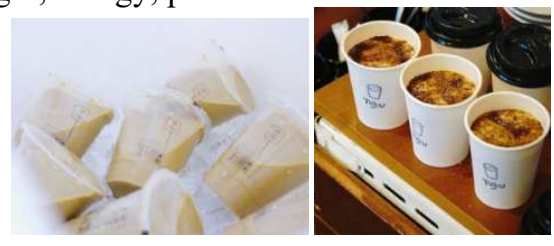

Figure 3.7Tuku's Packaging

Source : Tuku official instagram account

Unlike the previous 3 coffee brands, fore did not use black as the dominant color of the packaging. The fore packaging design is also more complex compared to tuku, kopi kenangan and janji jiwa.

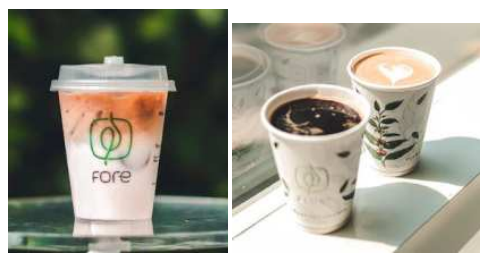

Figure 3.8Fore's Packaging

Source : Fore official instagram account

Same with kopi kenangan and tuku, fore uses white as the base color of the hot coffee packaging. But fore uses two other colors namely green and red. Iced fore packaging is also made of transparent plastic so that the color of coffee is seen. Unlike the previous 3 brands that used black for their logo, fore used green. Green psychologically can help someone who is depressed to balance his emotions and facilitate openness in communication.Graphic designers and publishers utilize color symbolism in order to evoke specific emotions [11] Here are table that filled with color emotion guide :
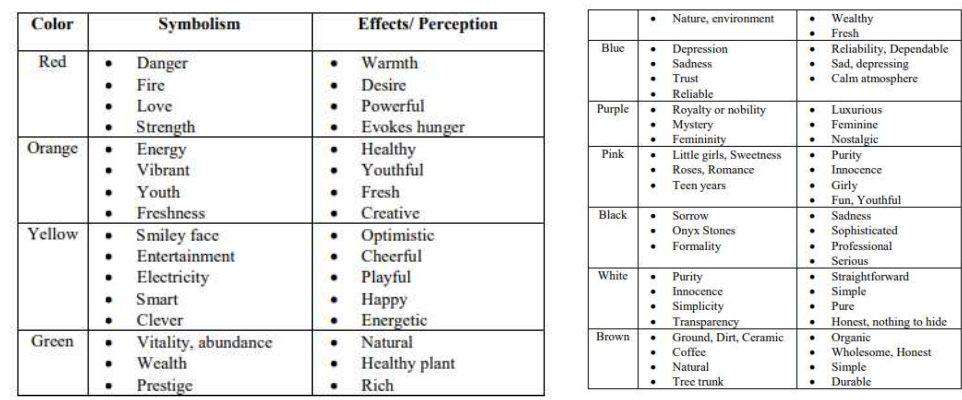

Table. 3.1 Color Emotion Guide [12] 
The following table contains an analysis of 4 samples of local coffee brands based on color emotions and sorted from dominant colors to non-dominant colors:

\begin{tabular}{|c|l|l|l|}
\hline No. & \multicolumn{1}{|c|}{ Brand } & \multicolumn{1}{c|}{ Warna } & \multicolumn{1}{c|}{ Makna } \\
\hline 1 & Janji Jiwa & 0 & Elegant, mysterious, faith and undoubtable quality. \\
\hline 2 & Kopi Kenangan & $\begin{array}{l}\text { Faith, undoubtable quality, elegant, mysterious, brave, } \\
\text { strong and happy. }\end{array}$ \\
\hline 3 & Tuku & 0 & Elegant and mysterious. \\
\hline 4 & Fore & 0 & $\begin{array}{l}\text { Faith, undoubtable quality, balance, calm, brave, } \\
\text { strong, happy, elegant and myterious. }\end{array}$ \\
\hline
\end{tabular}

After analyzing the packaging design using color emotions now, the packaging design will be analyzed using the theory of perception psychology. Visual communication design is very closely related to the psychology of perception. A visual communication design work including packaging design must be able to affect the target psychologically. Based on a research by David Walter after the target psychology is affected, then the target will take action according to what we want.[13] In the case of the design of this local coffee brand packaging, the packaging becomes a running advertisement. Where the target area is broad and its location is almost unlimited. The majority of the target market for local coffee brand is very broad, they are teenagers to parents. This broad target must be influenced psychologically to become a coffee consumer.

The human sense that most influences psychology is the sense of sight. Then the packaging design must be visually appealing to be a stimulus and influence the psychology of the target market. Compared to a research by Mohede 2018 and Ansari, Ahsan 2019 that packaging has an impact to consumer behaviour, this research focus on how color in packaging take an effect to consumer psychology. Also compared to Casas 2019 that focused on how color impact consumer in buying product apparel this research has case study in Coffee Packaging. The janjijiwa, kopi kenangan, and Tuku packaging designs have simple visuals with minimal colors. These three coffee brands use black as their dominant color. Psychologically this design gives an elegant and mysterious perception. So the target market that dominated by young people is psychologically influenced to consume both the coffee product and the identity that local coffee brand offered.

\section{CONCLUSION}

An understanding of color psychology and the psychology of perception is very important in building brand image and in delivering messages to target markets. In the target market of local coffee brand, black and white and also simple designs can influence the target market psychology of 17-35 years old to consume their products. An elegant and mysterious identity that is most sought after by this target market. This study explains that a good packaging design can not only sell products but also offer an identity. 


\section{REFERENCES}

[1]. Gumulya, Devanny, and Ivana Stacia Helmi, "Kajian budayaminum kopi Indonesia," JurnalDimensiSeni Rupa dan Desain, 13.2, pp.153-172, 2017.

[2]. Said, Irwanti, "Warung Kopi dan Gaya Hidup Modern," Jurnal Al-Khitabah, 3.3, 2017.

[3]. Aryani, DewiIsma, "Tinjauan Sensory Branding dan PsikologiDesainKedai Kopi KekinianTerhadapPerilakuKonsumen (StudiKasus: Mojo Coffee)," JurnalWacaCiptaRuang, pp.330-336, 2019.

[4]. Casas, Maria Carina, and Justine Chinoperekweyi, "Color Psychology and Its Influence on Consumer Buying Behavior: A Case of Apparel Products," 2019.

[5]. Putri, Sindy Yulia, and Syahrul Salam, "The Role of Indonesian Government in Improving Coffee Competitiveness in The EU-Indonesia Partnership and Cooperation Agreement Framework," Book Chapters of The 1st Jakarta International Conference on Social Sciences and Humanities (JICoSSH), Vol. 3, 2019.

[6]. Solikatun, Solikatun, Drajat Tri Kartono, and ArgyoDemartoto, "PerilakuKonsumsi Kopi SebagaiBudaya Masyarakat Konsumsi (StudiFenomenologi Pada Peminum Kopi Di Kedai Kopi Kota Semarang)," Jurnal Analisa Sosiologi, Vol.4.1, 2018.

[7]. Mohede, Christian Elroy, WJF Alfa Tumbuan, and Maria VJ Tielung, "Analysis of Packaging Elements and It's Impact to Consumers Buying Decisions Using Factor Analysis Tool On Coffee Packaging Products," Jurnal EMBA: JurnalRisetEkonomi, Manajemen, Bisnis dan Akuntansi, Vol.6.2, 2018.

[8]. Chitturi, Ravi, Juan Carlos Londono, and Carlos Alberto Amezquita, "The Influence of Color and Shape of Package Design on Consumer Preference: The Case of Orange Juice," International Journal of Innovation and Economic Development, Vol. 5.2, pp.42-56, 2019.

[9]. Ansari, Ahsan, Muhammad Usama, and Danish Ahmed Siddiqui, "Packaging Features and Consumer Buying Behavior Towards Packaged Food Items," Packaging Features and Consumer Buying Behavior towards Packaged Food Items, Global Scientific Journal, Vol.7.3, pp.1050-1073, 2019.

[10].Bleicher, S, Contemporary Colour: Theory \& Use. New York: Delmar, 2012.

[11].Kallen, S, Graphic Design. Detroit: Lucent Books, 6-10, 2009.

[12].Moorthi, Y, Branding Principles Application to Business-to-Business Branding. SSRN Electronic Journal, Vol.8, 2002.

[13].Hamlyn, David Walter, The psychology of perception: A philosophical examination of Gestalt theory and derivative theories of perception. Routledge, 2017. 